\title{
Posterior Uveitis
}

National Cancer Institute

\section{Source}

National Cancer Institute. Posterior Uveitis. NCI Thesaurus. Code C35111.

An inflammatory process that affects the choroid. 